\title{
Aplikasi Pelayanan Jasa Laundry Di Zazi Laundry Berbasis Web Dan Nexmo SMS API
}

\author{
Nanda Dwi Dzikrillah*¹, Maulidiansyah ${ }^{2}$, Mochammad Faid ${ }^{3}$ \\ ${ }^{1,2,3}$ Prodi Informatika Fakultas Teknik Universitas Nurul Jadid \\ Karanganyar Paiton Probolinggo \\ e-mail: *11 dikdork27@gmail.com, ${ }^{2}$ maulid@unuja.ac.id, ${ }^{3}$ mfaid@unuja.ac.id
}

\begin{abstract}
Abstrak
Zazi laundry adalah penyedia jasa mencuci pakaian yang berdiri sejak april 2018 dan terletak di desa sumberanyar kecamatan paiton, memiliki letak yang strategis sehingga setiap hari banyak yang menggunakan jasa Zazi laundry setiap. Zazi laundry memberikan pelayanan yang cukup baik kepada pelanggan, akan tetapi saat ini Zazi laundry masih menggunakan sistem secara manual dan belum menggunakan sistem palayanan yang memadai, sehingga untuk menyimpan data masih menggunakan buku. Dengan sistem yang masih secara manual ini menyulitkan karyawan atau pegawai dalam pembuatan laporan serta data pelanggan yang tersimpan dibuku sulit untuk dicari dan transaksi yang dilakukan membutuhkan waktu lama karena harus melakukan perhitungan secara manual. Berdasarkan permasalahan telah dijelaskan, maka dibutuhkan system Aplikasi Pelayanan Jasa Laundry Di Zazi Laundry Berbasis Web Dan Nexmo SMS API menggunakan metode pengembangan model waterfall yang dapat mempermudah dan mempercepat karyawan dalam melakukan pelayanan serta mempermudah pelanggan untuk mendapatkan informasi terkait pengambilan laundry dan paket yang tersedia. Model waterfall menyediakan pendekatan alur hidup perangkat lunak secara sekuential atau terurut dimulai dari analisis, desain, pengkodean, pengujian, dan tahap pendukung. Berdasarkan hasil pengujian blackbox diperoleh kesimpulan bawah semua fitur telah sesuai dan dari pengujian eksternal diperoleh nilai presentase sebesar $83 \%$, sehingga dikatakan sangat baik dan layak untuk digunakan.
\end{abstract}

Kata kunci: Zazi Laundry, Nexmo SMS API, Waterfall.

\begin{abstract}
Zazi Laundry is a clothes washing service provider that was established in April 2018 and is located in Sumberanyar Village, Paiton District, has a strategic location so that every day many use Zazi Laundry services every day. Zazi laundry provides a fairly good service to customers, but currently Zazi laundry still uses a manual system and has not used an adequate service system, so to store data it still uses books. With a system that is still manual, it makes it difficult for employees or employees to make reports and customer data stored in the book is difficult to find and transactions carried out take a long time because they have to do calculations manually. Based on the problems described, it is necessary to have a Laundry Service Application System at Zazi Laundry Web-Based and Nexmo SMS API using the waterfall model development method that can simplify and speed up employees in performing services and make it easier for customers to get information related to picking up laundry and available packages. The waterfall model provides a sequential software lifeflow approach starting from the analysis, design, coding, testing, and support stages. Based on the results of the blackbox test, it was concluded that all features were appropriate and from external testing, a percentage value of $83 \%$ was obtained, so it was said to be very good and feasible to use.
\end{abstract}

Keywords: Zazi Laundry, Nexmo SMS API, Waterfall. 


\section{PENDAHULUAN}

Pada Perkembangan zaman yang semakin modern membuat gaya hidup juga semakin modern, salah satu contohnya adalah adanya tempat khusus untuk mencuci atau yang biasa disebut Laundry. Laundry adalah jasa binatu (laundry) dengan biaya jasa yang kompetitif dan terjangkau. Bisnis laundry ini dirasa menguntungkan karena banyak orang yang tidak sempat mencuci sendiri dan juga bagi yang tidak mempunyai banyak waktu (pekerja) atau sebagian besar adalah mahasiswa [1]. Zazi laundry adalah penyedia jasa mencuci pakaian yang berdiri sejak april 2018 dan terletak di desa sumberanyar kecamatan paiton, memiliki letak yang strategis sehingga setiap hari banyak yang menggunakan jasa Zazi laundry setiap. Zazi laundry buka dari jam 08.00 - 16.00 serta menawarkan beberapa paket seperti paket cuci lipat yang harganya Rp. 4.000/kg dan paket cuci setrika Rp. 5.500/kg dan Zazi laundry memiliki 6 mesin cuci yang bisa digunakan serta memperkerjakan 6 karyawan. Selain mencuci pakaian Zazi laundry juga menawarkan cuci karpet, cuci selimut, cuci kursi sofa dan lain - lain.

Zazi laundry memberikan pelayanan yang cukup baik kepada pelanggan, akan tetapi saat ini Zazi laundry masih menggunakan sistem secara manual dan belum menggunakan sistem palayanan yang memadai, sehingga untuk menyimpan data masih menggunakan buku. Dengan sistem yang masih secara manual ini menyulitkan karyawan atau pegawai dalam pembuatan laporan serta data pelanggan yang tersimpan dibuku sulit untuk dicari dan transaksi yang dilakukan membutuhkan waktu lama karena harus melakukan perhitungan secara manual. Salah satu upaya dalam meningkatkan kualitas layanan adalah dengan menerapkan suatu sistem pencatatan dan pengolahan data transaksi yang baik dan terstruktur sehingga semua informasi yang diperlukan dapat dihasilkan secara cepat dan akurat [2]. Pelanggan juga tidak mendapatkan informasi tentang waktu pengambilan laundry serta tidak mengetahui paket yang tersedia di Zazi laundry.

Pada penelitian sebelumnya yang dilakukan oleh (Rachmatika \& Wulandari, 2019), dalam jurnalnya yang berjudul "Rancangan Aplikasi Laundry Berbasis Dekstop pada Krisna Laundry Untuk Wilayah Limo" menjelaskan bahwa di Krisna Laundry pengelolaan data transaksi belum menggunakan sistem terkomputerisasi, seperti pencatatan data pelanggan, data transaksi, dan pembuatan nota penyerahan dimana setiap kegiatannya masih disimpan di dalam buku besar. Dari hasil penelitian dapat disimpulkan bahwa pada Krisna Laundry sistem yang berjalan masih melakukan dengan cara pencatatan dengan perbandingan antara sistem yang dirancang atau diusulkan, maka penyusun dapat menyimpulkan bahwa sudah dan telah merancang sebuah sistem aplikasi pengolahan data customer yang mudah dan efisien serta sudah dan telah membuat sistem informasi penyimpanan data customer yang menjamin keamanan datanya [3].

Pada penelitian berikutnya yang dilakukan oleh (Mulyadi et al., 2019) dengan judul "Aplikasi Sistem Pemesanan Jasa Laundry (E-laundry) Berbasis Android" yang melatar belakangi penelitian tersebut yaitu Usaha laundry merupakan salah satu bisnis dibidang jasa cuci dan setrika pakaian, usaha ini memiliki perputaran yang cepat atau rentang waktu permintaan pelanggan antara permintaan pertama dan permintaan selanjutnya pada jasa ini yang memakan waktu relatif singkat. Kesimpulan dari penelitian ini adalah aplikasi sistem pemesanan jasa laundry (E-laundry) berbasis android ini dapat digunakan sebagai pemesanan jasa laundry secara online melalui aplikasi. Dengan adanya pembayaran secara digital dapat memudahkan dalam proses transaksi pada pemesanan jasa laundry. Aplikasi sistem pemesanan jasa laundry (E-laundry) dapat menjadi sentral bagi para pelaku laundry [4].

Penelitian ketiga oleh (Atina et al., 2020) dengan judul "Aplikasi Sistem Manajemen Laundry Berbasis Web" yang melatar belakangi peneltian tersebut yaitu Proses administrasi Pelangi laundry masih menggunakan sistem pencatatan melalui buku manual dan nota penerimaan. Pelangi laundry mengalami kesulitan dalam melakukan pencatatan penerimaan 
Laundry dan pencarian barang laundry yang memakan waktu cukup lama. Berdasarkan hasil penelitian dan analisis mengenai proses transaksi laundry pada pelangi laundry ditemukan beberapa kesimpulan diantaranya aplikasi manajemen laundry dapat digunakan untuk menambahkan customer baru, melakukan pencatatan laundry, menambahkan paket laundry dan membuat laporan [5].

Dari ketiga hasil penelitian diatas, perbedaan ketiga penelitian tersebut dengan penelitian yang dikerjakan adalah pada penelitian pertama menggunakan perangkat dekstop dalam membangun aplikasi laudry, penelitian kedua menggunakan perangkat android dan juga menggunakan LBS (Location Based Service), pada penelitian ketiga membangun aplikasi laundry menggunakan web dengan metode Sistem Development Life Cycle (SDLC). Sedangkan penelitian yang saat ini dibangun difokuskan pada pelayanan jasa laundry berbasis web dan SMS gateway sebagai penyampaian informasi kepada pelanggan terkait pengambilan laundry di Zazi laundry.

Berdasarkan uraian masalah yang telah dijelaskan, maka untuk mempermudah dan mempercepat pelayanan dibutuhkan sistem yang memadai sehingga pelanggan mudah dalam mendapatkan informasi terkait pengambilan laundry dan paket yang tersedia. Website adalah sebagai kumpulan halaman yang menampilkan informasi data teks, data gambar, data animasi, suara, video dan gabungan dari semuanya, baik yang bersifat statis maupun dinamis yang membentuk satu rangkaian bangunan yang saling terkait, dimana masing-masing dihubungkan dengan jaringan-jaringan halaman (hyperlink)[6]. Aplikasi Pelayanan Jasa Laundry Di Zazi Laundry Berbasis Web Dan Nexmo SMS API adalah solusi yang dapat diambil untuk mengatasi permasalahan diatas. Dengan menggunakan SMS Gateway diharapkan pelanggan bisa mendapatkan informasi tentang waktu pengambilan laundry yang telah selesai. SMS Gateway adalah suatu platform yang menyediakan mekanisme untuk End User Application (EUA) menghantar dan menerima SMS dari peralatan mobile (HP, PDA phone, dll) melalui SMS Gateway's shortcode [7].

\section{METODE PENELITIAN}

Menurut Sugiyono (2007: 1) Metode penelitian kualitatif adalah jenis penelitian yang menggunakan peneliti sebagai alat utama, dipadukan dengan teknologi pengumpulan data. Analisis data bersifat induktif, dan hasil penelitian kualitatif lebih menekankan pada makna daripada generalisasi [8]. Untuk pengembangan penelitian ini menggunakan SDLC atau System Development Life Cycle. Model SDLC yang dipakai dalam penelitian ini adalah model Waterfall [9]. Perangkat lunak yang bersifat generik cocok dalam menggunakan model pengembangan waterfall, artinya semua kebutuhannya dari awal dengan spesifikasi yang umum dapat diidentifikasi.

Model SDLC air terjun (waterfall) biasanya disebut juga model urutan linier (linear Sequential) atau siklus hidup klasik (classic life cycle). Model air terjun menyediakan pendekatan aliran hidup perangkat lunak sekuensial mulai dari analisis, desain, pengkodean, pengujian, dan fase dukungan [10]. Gambar 1 merupakan gambaran fase atau tahapan pada model waterfall sebagai berikut : 


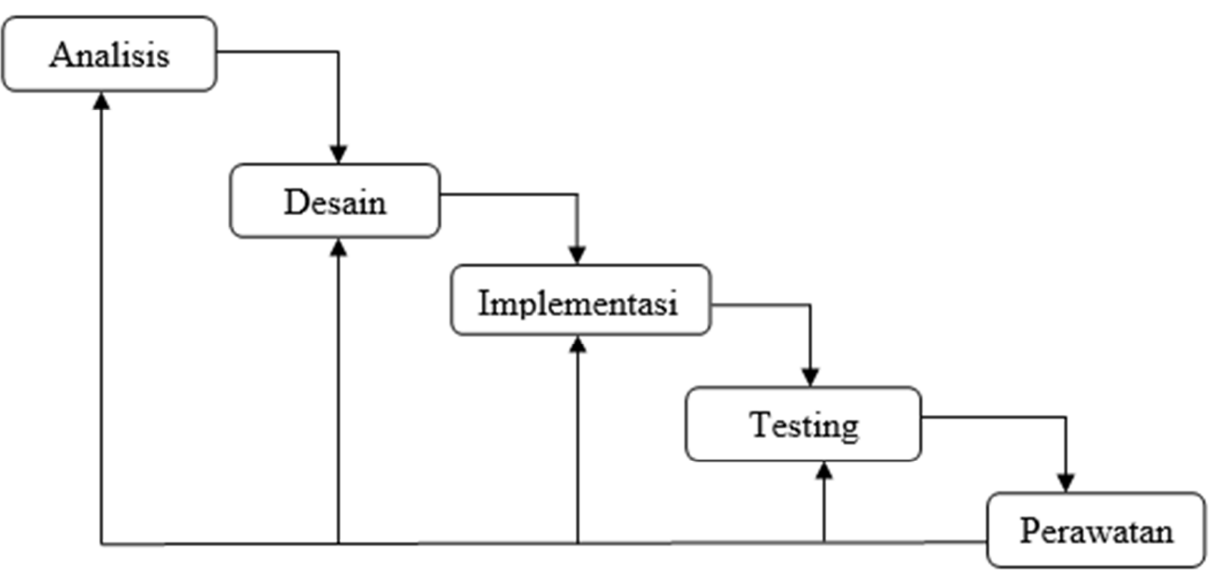

Gambar 1. Model Waterfall [10]

\subsection{Rekayasa Kebutuhan (Requirement)}

Proses membentuk layanan dan batasan sistem yang akan beroperasi serta yang dibutuhkan pelanggan dari suatu sistem biasa disebut Rekayasa Kebutuhan.

a. Kebutuhan Fungsional

Kebutuhan fungsional adalah kebutuhan dengan sistem yang memiliki keterkaitan langsung. Kebutuhan fungsional aplikasi ini meliputi:

1. Kebutuhan fungsional user

2. Kebutuhan fungsional pengelola

b. Kebutuhan Non-Fungsional

Kebutuhan non-fungsional adalah kebutuhan di dalam sistem yang tidak secara langsung terkait dengan fitur tertentu.

1. Kebutuhan perangkat keras (Hardware)

Adapun yang digunakan dalam membangun aplikasi ini adalah dengan menggunakan sebuah notebook dengan sepesifikasi sebagai berikut:

- Prosesor AMD E-350 APU

- RAM 4 GB

- Harddisk 500GB

2. Kebutuhan perangkat lunak (Software) berikut:

Adapun software yang digunakan untuk membangun aplikasi ini adalah sebagai

- Visual Studio Code

- Google Chrome sebagai web browsernya.

\subsection{Desain}

Pada tahap ini dilakukan perancangan sistem yang akan dibangun. Hasil analisis kebutuhan sistem dipertimbangkan dalam membuat desain. Penelitian ini akan dilakukan dalam beberapa tahap, yaitu: Flowchart, Data Flow Diagram (DFD), dan Entity Relationship Diagram (ERD). Tahapan ini akan dibahas pada bab selanjutnya.

\subsection{Implementasi}

Setelah sistem berhasil dirancang, langkah selanjutnya adalah mengimplementasikan desain sebagai kode program. Pada penelitian ini bahasa pemrograman PHP digunakan dalam mengimplementasi desain. Sedangkan basis data menggunakan MySQL. 


\subsection{Pengujian (Testing)}

Pengujian adalah tahap paling penting dari model pengembangan waterfall. Tanpa tahapan ini tidak mungkin dapat diketahui apakah sistem yang telah dibuat telah mencapai tujuan ataukah merupakan solusi dari permasalahan yang ada. Dalam pengujian sistem akan dihasilkan sebuah kesuksesan dan kesalahan dalam bentuk tabel uji.

a. Pengujian Internal (Black Box)

Setelah tahap pengujian selesai dan aplikasi yang dibuat telah sesuai maka tahap selanjutnya adalah menerapkan aplikasi tersebut. Dan dilanjutkan dengan melakukan perawatan terhadap aplikasi tersebut.

b. Pengujian Eksternal (User)

Setelah tahap pengujian selesai dan aplikasi yang dibuat sesuai harapan maka tahap selanjutnya adalah skala Likert dimana analisa data instrumen validasi ahli. Skala Likert adalah skala pengukuran psikologis yang biasa digunakan dalam kuesioner, dan merupakan skala yang paling banyak digunakan dalam penelitian, dalam bentuk survey [11]. Berikut langkah-langkah dalam menganalisa angket menggunakan skala Likert:

1. Kuesioner

Pengembangan kuesioner ini bertujuan untuk mendapatkan variabel data kualitatif dengan mengukur hasil tanggapan pengguna. Isi angket dapat berupa pernyataan fakta, pernyataan pendapat dan pernyataan kognisi diri. Berikut ini adalah pernyataan yang akan digunakan untuk pengembangan kuesioner dan tahap selanjutnya.

Tabel 1. Kisi-kisi Kuesioner Untuk Responden

\begin{tabular}{|c|l|l|l|l|l|}
\hline \multirow{2}{*}{ No. } & \multicolumn{1}{|c|}{ Pertanyaan } & \multicolumn{3}{|l|}{ Kesimpulan } \\
\cline { 3 - 6 } 1 & $\begin{array}{l}\text { Apakah menurut anda aplikasi pelayanan } \\
\text { laundry ini sudah layak digunakan di Zazi } \\
\text { Laundry? }\end{array}$ & & & & \\
\hline 2 & $\begin{array}{l}\text { Apakah dengan aplikasi laundry ini dapat } \\
\text { mempermudah dalam pengolahan data dan } \\
\text { transaksi? }\end{array}$ & & & & \\
\hline 3 & Apakah anda menyukai aplikasi laundry ini? & & & & \\
\hline 4 & $\begin{array}{l}\text { Apakah aplikasi laundry ini memiliki } \\
\text { kecepatan transfer data yang optimal? }\end{array}$ & & & \\
\hline 5 & $\begin{array}{l}\text { Apakah aplikasi laundry ini sederhana dan } \\
\text { mudah digunakan dalam mengoperasikan }\end{array}$ & & & & \\
\hline
\end{tabular}

Adapun untuk melihat seberapa besar penilaian yang diberikan, berikut cara dan metode yang digunakan.

a) Indikator variable

Tabel 2. Indikator Dalam Skala Likert

\begin{tabular}{|c|l|}
\hline Skor & \multicolumn{1}{c|}{ Alternatif Jawaban } \\
\hline 4 & Sangat Setuju (SS) \\
\hline 3 & Setuju (S) \\
\hline 2 & Tidak Setuju (TS) \\
\hline 1 & Sangat Tidak Setuju (STS) \\
\hline
\end{tabular}

b) Penilaian untuk masing-masing survey

1) Skor perolehan = Jumlah skor semua responden

2) Jumlah skor ideal = skor tertinggi $\mathrm{x}$ jumlah soal $\mathrm{x}$ jumlah responden 
3) $\mathrm{P}=$ Penentuan skor

4) rumus :

c) Skala Interpretasi (Rating Scale)

$$
P=\left(\frac{\text { skor perolehan }}{\text { skor ideal }}\right) \times 100 \%
$$

Skala interpretasi dibuat dengan membagi skor ideal menjadi 4 bagian secara kontinium. Skor idealnya adalah $100 \%$ :

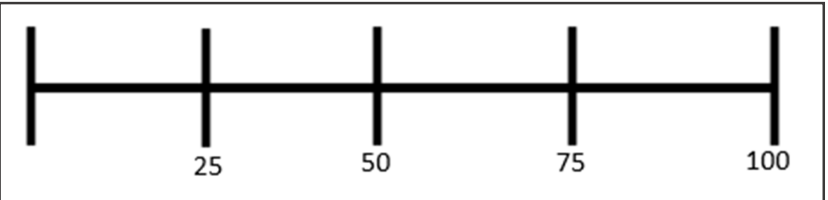

Gambar 2. Skala Interpretasi Likert (Rating Scale) [11]

Dalam tahap ini, data kuisioner dari responden dapat diklasifikasi apakah aplikasi pelayanan laundry yang ada di Zazi Laundry layak atau tidak.

Tabel 3. Skor Jawaban Responden

\begin{tabular}{|l|l|}
\hline Skor Presentase & Interpretasi \\
\hline $25(\%)$ & Tidak Baik \\
\hline $26-50(\%)$ & Kurang Baik \\
\hline $51-75(\%)$ & Baik \\
\hline $76-100(100 \%)$ & Sangat Baik \\
\hline
\end{tabular}

\section{HASIL DAN PEMBAHASAN}

Seperti dijelaskan pada proses sebelumnya, model pengembangan sistem dalam penelitian ini menggunakan metode waterfall yang proses pengembangannya berurutan atau bertahap. Model pengembangan perangkat lunak waterfall seperti yang dijelaskan pada pembahasan sebelumnya terdiri dari 5 tahapan, yaitu tahap analisis kebutuhan, tahap desain, tahap implementasi dan pengujian unit, tahap integrasi dan pengujian sistem dan tahap pemeliharaan sistem.

\subsection{Tahap Analisis Kebutuhan}

Proses analisis kebutuhan untuk aplikasi yang akan dibuat dilakukan dengan melakukan observasi dan wawancara seperti yang telah dipaparkan sebelumnya. Adapun hasil dari analisis kebutuhan terbagi menjadi dua jenis analisis sistem, berupa analisis sistem lama dan analisis sistem baru.

1. Hasil Analisa Sistem Lama

Setelah mengetahui permasalahan yang ada maka perlu adanya sebuah aplikasi yang dapat membantu dan mengatasi masalah-masalah yang ada. Adapun aplikasi ini dapat membantu pengelola dan juga petugas laundry dalam mengolah data dan pembuatan laporan keuangan. Semua proses pendataan dilakukan secara cepat dan tepat, sehingga kesalahan data tidak akan terjadi. 


\section{Hasil Analisis Sistem Baru}

Setelah mengetahui permasalahan yang ada maka perlu adanya sebuah aplikasi yang dapat membantu dan mengatasi masalah-masalah yang ada. Adapun aplikasi ini dapat membantu pengelola dan juga petugas laundry dalam mengolah data dan pembuatan laporan keuangan. Semua proses pendataan dilakukan secara cepat dan tepat, sehingga kesalahan data tidak akan terjadi.

\subsection{Desain Sistem}

Pada tahap ini mengubah kebutuhan perangkat lunak dari tahap analisis kebutuhan ke representasi desain agar dapat diimplementasikan menjadi program dalam tahap selanjutnya. Tahapan-tahapan desain ini meliput alur sistem (Flowchart), alur data atau Data Flow Diagram(DFD), Entity Relationship Diagram(ERD), desain table dan desain tampilan aplikasi (application interface). Berikut penjelasan dari tahapan-tahapan yang telah disebutkan diatas.

1. Alur Sistem

Sistem flowchart akan menggambarkan alur kerja proses Sistem Informasi Manajemen Laundry dalam pendataan pakaian masuk dan keluar, mengolah data pelanggan dan pembuatan laporan. Berikut adalah gambaran flowchart sistem baru yang diterapkan.

a) Flowchart Sistem Lama

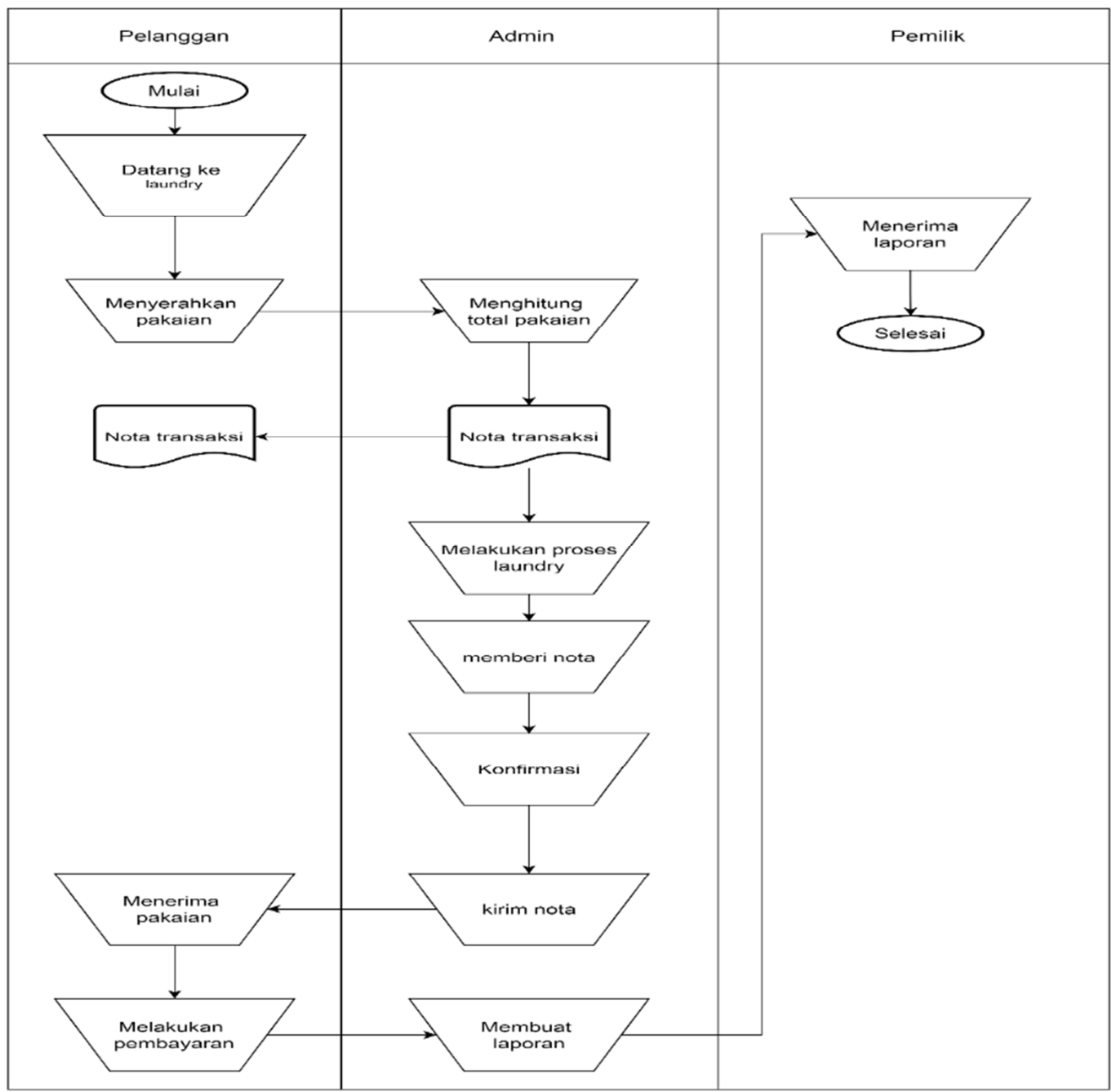

Gambar 3. Flowchart Sistem Lama 
b) Flowchart Sistem Baru

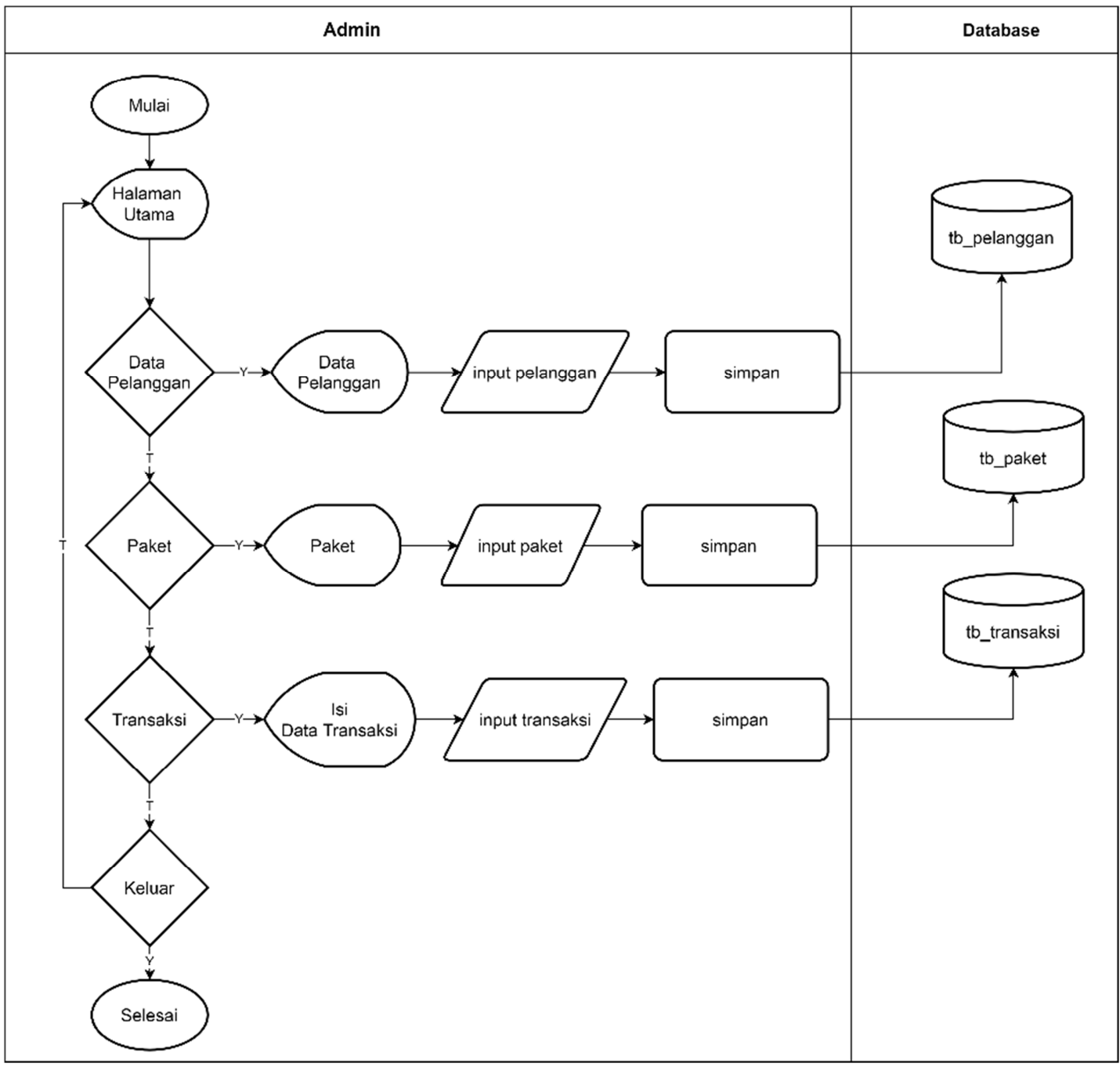

Gambar 4. Flowchart Sistem Lama

\subsection{Implementasi}

1. Screenshoot Aplikasi 


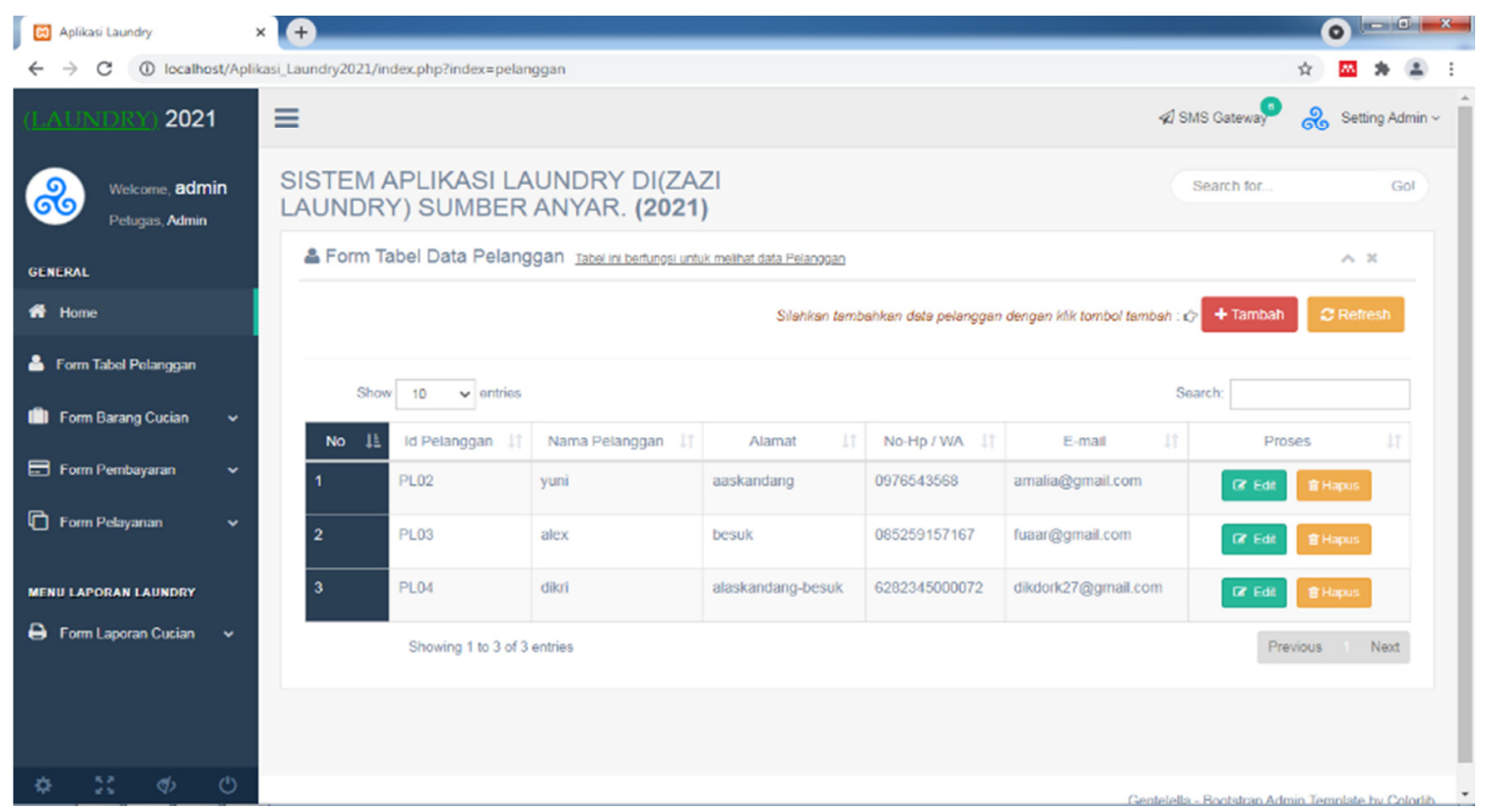

Gambar 5. Screenshot Form Pelanggan

Gambar 5 ini merupakan form yang digunakan oleh admin untuk menginputkan data pelanggan.

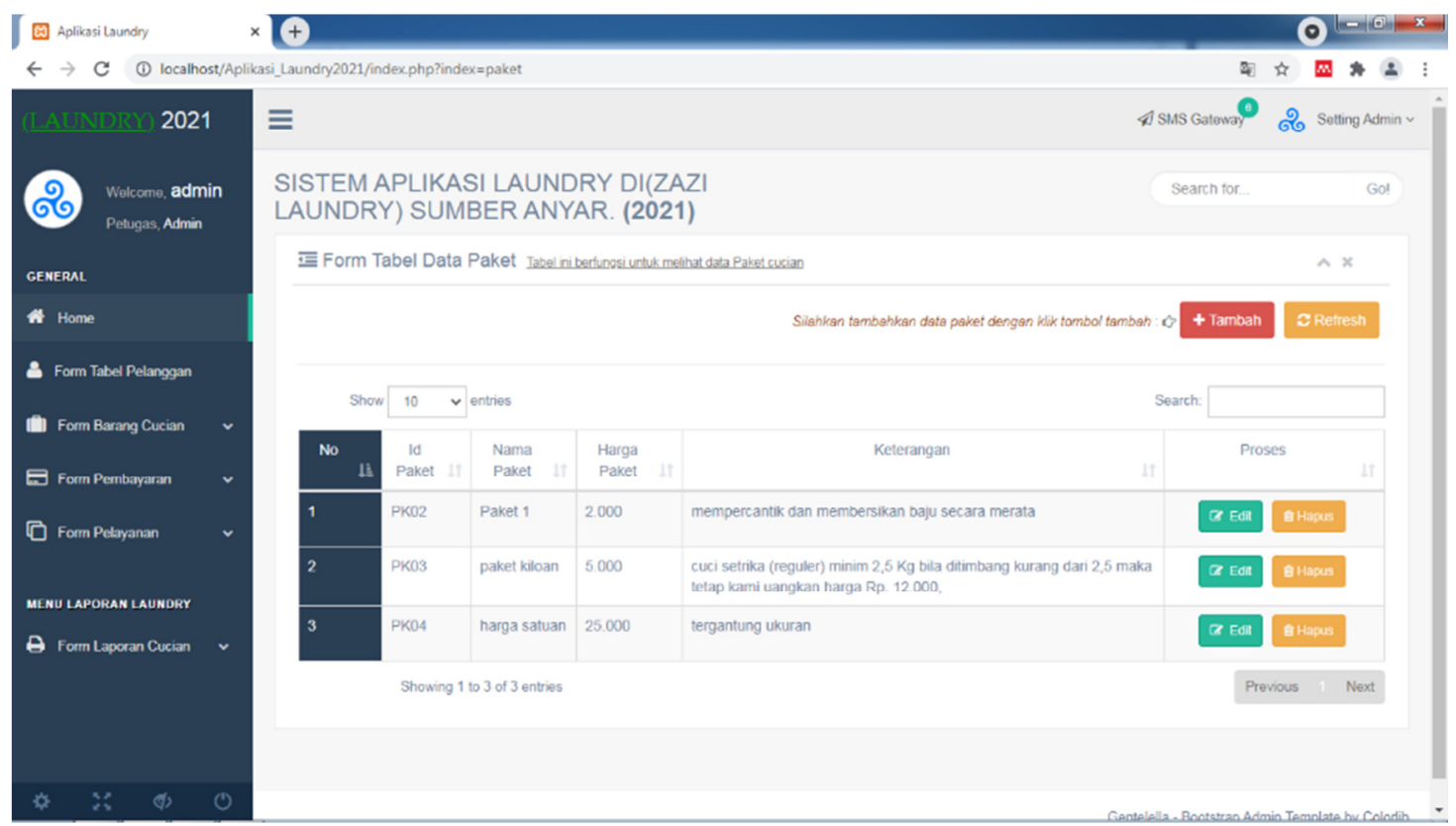

Gambar 6. Screenshot Form Paket Laundry

Gambar 6 diatas digunakan untuk menambahkan paket yang tersedia di Zazi laundry, seperti paket kiloan, paket satuan, dan paket lainnya. 


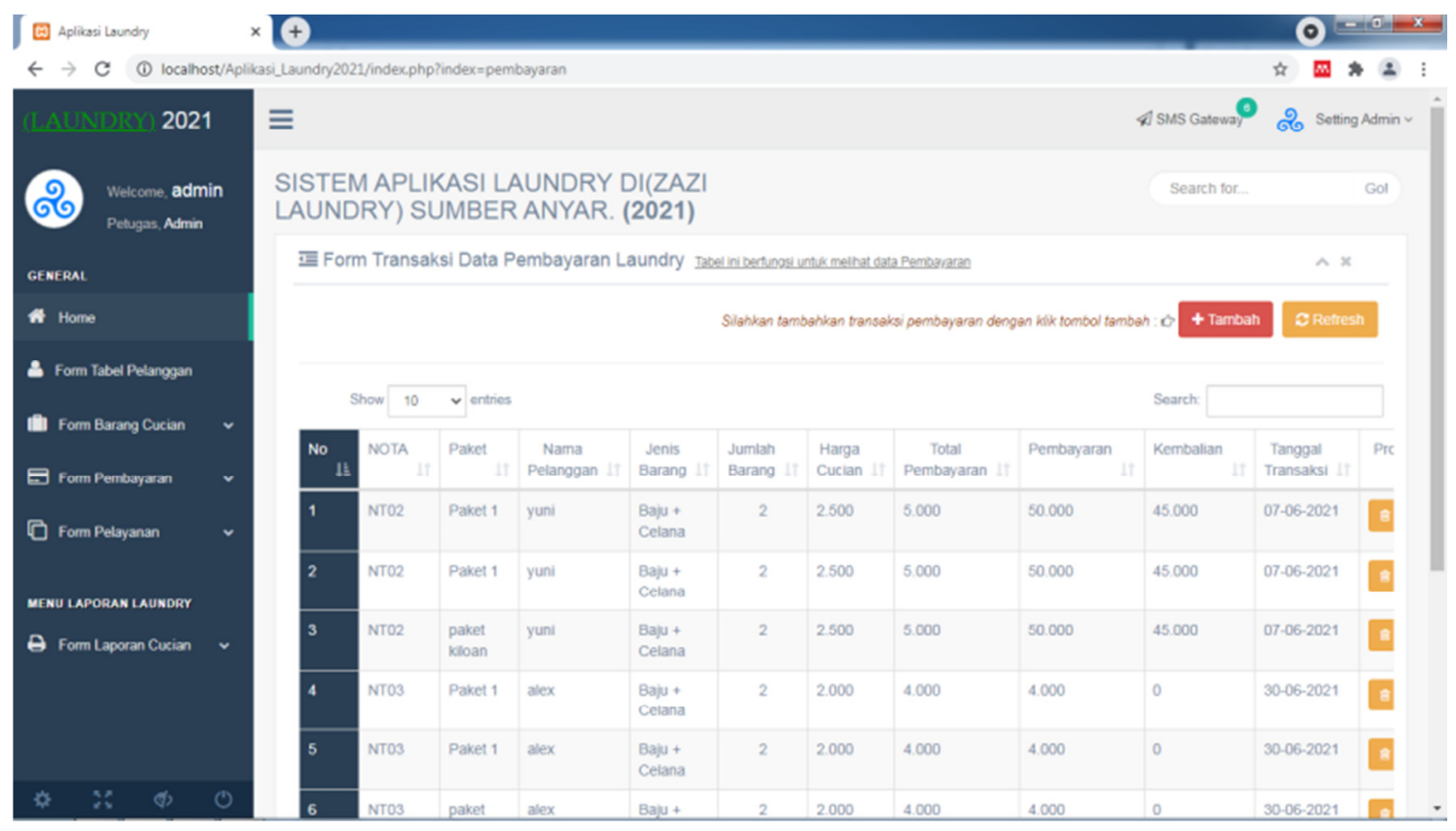

Gambar 7. Screenshot Form Transaksi

Gambar 7 ini merupakan form yang digunakan oleh admin atau petugas dalam melakukan transaksi.

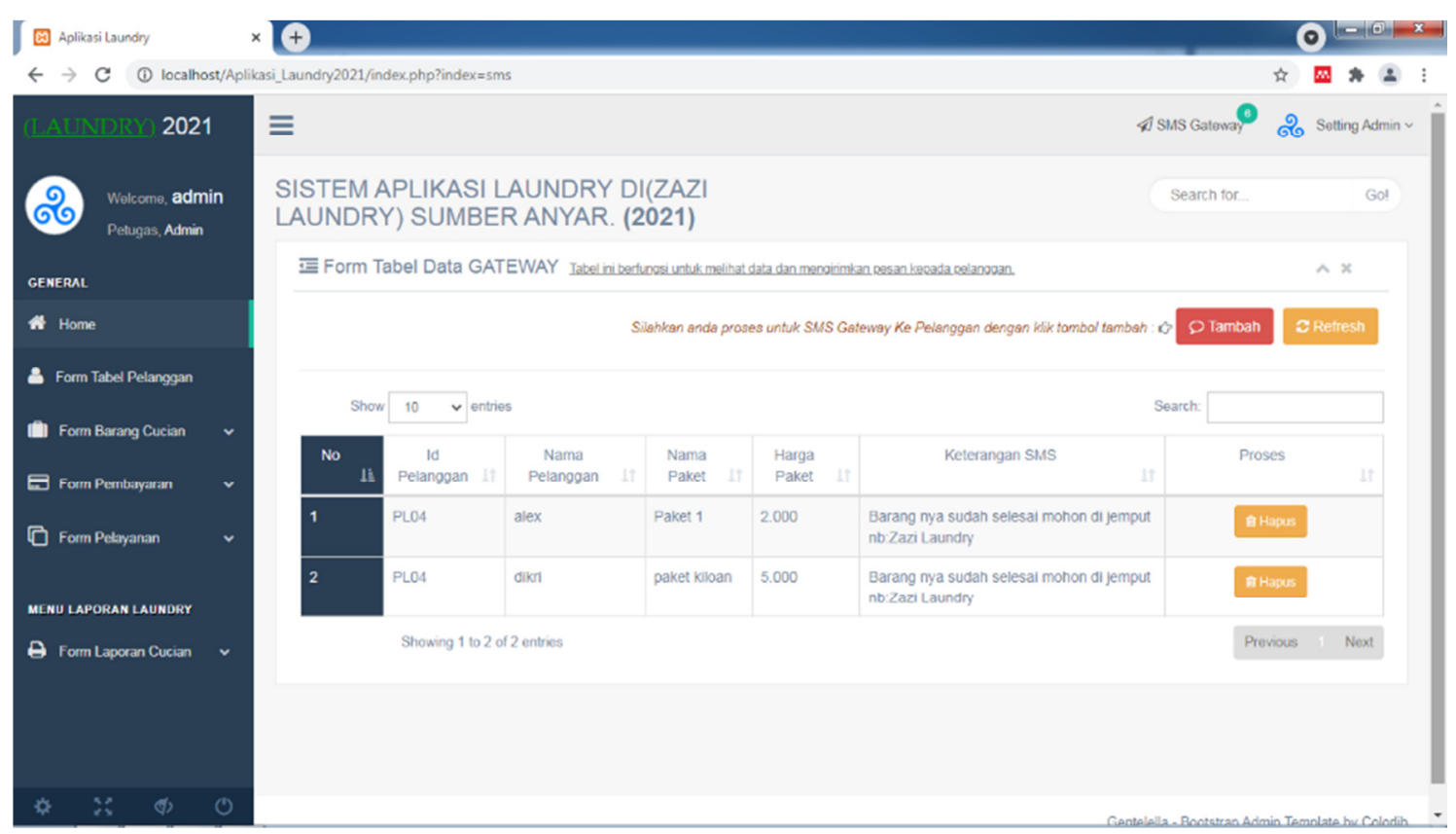

Gambar 8. Screenshot Form SMS Gateway 
2. Hasil Uji

1. Pengujian Black Box

Setelah tahap pengujian selesai dan aplikasi yang dibuat telah sesuai dengan yang diharapkan maka tahap selanjutnya adalah menerapkan aplikasi tersebut. Dan dilanjutkan dengan melakukan perawatan terhadap aplikasi tersebut. Hasil pengujian Black Box ditunjukkan pada tabel 4.

Tabel 4. Pengujian Blackbox

\begin{tabular}{|c|c|c|c|c|c|}
\hline \multirow{2}{*}{ No. } & \multirow{2}{*}{$\begin{array}{l}\text { Unit } \\
\text { Uji }\end{array}$} & \multirow{2}{*}{$\begin{array}{l}\text { Masukan/ } \\
\text { Kondisi }\end{array}$} & \multirow{2}{*}{ Hasil yang diharapkan } & \multicolumn{2}{|c|}{ Kesesuaian } \\
\hline & & & & $\mathrm{Ya}$ & Tidak \\
\hline \multirow{2}{*}{1} & \multirow{2}{*}{ Login } & \multirow{2}{*}{$\begin{array}{l}\text { Akses untuk } \\
\text { menuju ke } \\
\text { menu utama }\end{array}$} & $\begin{array}{l}\text { Jika username dan password } \\
\text { sesuai maka program akan } \\
\text { melanjutkan ke menu utama. }\end{array}$ & $\checkmark$ & \\
\hline & & & $\begin{array}{l}\text { Jika tidak sesuai maka program } \\
\text { tidak akan melanjutkan ke menu } \\
\text { utama. }\end{array}$ & $\checkmark$ & \\
\hline \multirow{8}{*}{2} & \multirow{8}{*}{$\begin{array}{l}\text { Menu } \\
\text { Utama }\end{array}$} & \multirow{2}{*}{$\begin{array}{l}\text { Memilih } \\
\text { menu Petugas }\end{array}$} & - Menampilkan data karyawan. & $\checkmark$ & \\
\hline & & & - Dapat mengelolah data karyawan. & $\checkmark$ & \\
\hline & & \multirow{2}{*}{$\begin{array}{l}\text { Memilih } \\
\text { menu } \\
\text { pelanggan }\end{array}$} & - Menampilkan data pelanggan. & $\checkmark$ & \\
\hline & & & - Dapat mengolah data pelanggan. & $\checkmark$ & \\
\hline & & $\begin{array}{l}\text { Memilih } \\
\text { Paket }\end{array}$ & $\begin{array}{l}\text { - Dapat menentukan tarif pakaian } \\
\text { per- kg. }\end{array}$ & $\checkmark$ & \\
\hline & & $\begin{array}{l}\text { Memilih } \\
\text { menu } \\
\text { transaksi }\end{array}$ & $\begin{array}{l}\text { - Dapat mencatat data pakaian } \\
\text { masuk dengan model penginputan } \\
\text { tanggal secara otomatis (real } \\
\text { time). }\end{array}$ & $\checkmark$ & \\
\hline & & $\begin{array}{l}\text { Memilih } \\
\text { menu SMS } \\
\text { Gatewway }\end{array}$ & $\begin{array}{l}\text { - Dapat mengirimkan notifikasi } \\
\text { berupa SMS ke palnggang setelah } \\
\text { selesai. }\end{array}$ & $\checkmark$ & \\
\hline & & $\begin{array}{l}\text { Memilih } \\
\text { menu } \\
\text { laporan }\end{array}$ & $\begin{array}{l}\text { - Dapat membuat laporan keuangan } \\
\text { dengan menentukan tanggal yang } \\
\text { ingin direkap. }\end{array}$ & $\checkmark$ & \\
\hline 3 & $\begin{array}{l}\text { Log } \\
\text { Out }\end{array}$ & $\begin{array}{l}\text { Akses untuk } \\
\text { menutup } \\
\text { program }\end{array}$ & $\begin{array}{l}\text { Dapat menutup program (kembali } \\
\text { ke menu login) }\end{array}$ & $\checkmark$ & \\
\hline
\end{tabular}

3. Pengujian Eksternal (User)

Setelah tahap pengujian selesai dan aplikasi yang dibuat telah sesuai dengan yang diharapkan maka tahap selanjutnya adalah analisa data instrumen validasi ahli menggunakan skala Likert. Berikut langkah-langkah dalam menganalisa angket menggunakan skala Likert:

a. Kuesioner

Pada pengujian eksternal yang dilakukan untuk menguji aplikasi langsung terhadap pengguna. Peneliti menggunakan perhitungan kuesioner dengan skala likert yang digunakan untuk mengukur persepsi, sikap atau pendapat pengguna aplikasi yang dapat diaplikasikan dalam angket dan sering digunakan untuk riset yang berupa survei. Pada pengujian Aplikasi Sistem Informasi Manajemen Zazi Laundry Berbasis Web dilakukan pengujian kepada 5 petugas (sebagai pengelola laundry). 
Tabel 5. Kuesioner

\begin{tabular}{|c|l|l|l|l|l|l|}
\hline \multirow{2}{*}{ No. } & Pertanyaan & \multicolumn{4}{|l|}{ Kesimpulan } \\
\cline { 2 - 7 } 1 & $\begin{array}{l}\text { Apakah menurut anda aplikasi pelayanan } \\
\text { laundry ini sudah layak digunakan di Zazi } \\
\text { Laundry? }\end{array}$ & 3 & 2 & SS & STS \\
\hline 2 & $\begin{array}{l}\text { Apakah dengan aplikasi laundry ini dapat } \\
\text { mempermudah dalam pengolahan data dan } \\
\text { transaksi? }\end{array}$ & 4 & 1 & & \\
\hline 3 & Apakah anda menyukai aplikasi laundry ini? & 2 & 2 & 1 & \\
\hline 4 & $\begin{array}{l}\text { Apakah aplikasi laundry ini memiliki kecepatan } \\
\text { transfer data yang optimal? }\end{array}$ & 2 & 1 & 2 & \\
\hline 5 & $\begin{array}{l}\text { Apakah aplikasi laundry ini sederhana dan } \\
\text { mudah digunakan dalam mengoperasikan }\end{array}$ & 1 & 3 & 1 & \\
\hline
\end{tabular}

Jumlah skor perolehan dari semua responden:

$\begin{array}{lll}\text { Jumlah Sangat Setuju (SS) } & =12 \times 4 & \\ \text { Jumlah Setuju (S) } & =9 \times 3 & =27 \\ \text { Jumlah Tidak Setuju (TS) } & =4 \times 2 & =8 \\ \text { Jumlah Sangat Tidak Setuju (STS) } & =0 \times 1 & =0\end{array}$

Sehingga total perolehan skor dari semua responden adalah 83 .

Jumlah skor ideal diperoleh dari skor tertinggi $\mathrm{x}$ jumlah butir soal $\mathrm{x}$ jumlah responden $=4 \mathrm{x} 5 \mathrm{x}$ $5=100$

Tabel 6. Skor Presentase

\begin{tabular}{|l|l|}
\hline Skor Presentase & \multicolumn{1}{|c|}{ Interpretasi } \\
\hline $25(\%)$ & Tidak Baik \\
\hline $26-50(\%)$ & Kurang Baik \\
\hline $51-75(\%)$ & Baik \\
\hline $76-100(100 \%)$ & Sangat Baik \\
\hline
\end{tabular}

Rumus Penentuan Skor $=($ Skor Perolehan / Skor Ideal $) \times 100$ Perhitungan $(83 / 100) \mathrm{x}$ $100=83 \%$. Hasil perhitungan mengunakan metode skala likert didapatkan data sebanyak $83 \%$ yang artinya Aplikasi Sistem Informasi Manajemen Zazi Laundry berbasis Web ini sangat baik dan layak untuk digunakan.

\section{KESIMPULAN}

Setelah melakukan penelitian serta membahas hasil penelitian secara tuntas sehingga tercipta Aplikasi Pelayanan Jasa Laundry Di Zazi Laundry Berbasis Web Dan Nexmo Sms API, maka dapat di ambil kesimpulan bahwa Aplikasi yang telah dibangun dapat membantu dan mempermudah petugas laundry dalam melakukan proses transaksi dan perekapan laporan secara cepat dan efektif serta berdasarkan hasil kuesioner yang diperoleh nilai presentase sebesar $83 \%$, sehingga dikatakan sangat baik dan layak untuk digunakan. 


\section{SARAN}

Peneliti berharap aplikasi yang dibuat dapat berguna untuk petugas di Zazi Laundry dalam melakukan proses transaksi dan perekapan laporan secara cepat dan efektif. Adapun beberapa hal ini yang dapat dijadikan bahan pertimbangan bagi pengembangan sistem kedepannya:

1. Perlu adanya penambahan fitur Payment Gateway, sehingga pelanggan bisa melakukan pembayaran secara online.

2. Perlunya penambahan aplikasi untuk pelanggan sehingga pelanggan bisa melakukan pemesanan layanan laundry secara mandiri melalui aplikasi yang digunakan oleh pelanggan.

\section{UCAPAN TERIMA KASIH}

Penulis mengucapkan terima kasih kepada pihak Zazi Laundry yang telah memperbolehkan penulis melakukan penelitian dan uji sistem di tempat usaha laundry, serta bapak Maulidiansyah, M.Kom dan bapak Mochammad Faid, M.Kom sebagai dosen pembimbing yang telah membimbing penulis sampai akhir

\section{DAFTAR PUSTAKA}

[1] Destiningrum, M., \& Adrian, Q. J. 2017. Sistem Informasi Penjadwalan Dokter Berbassis Web Dengan Menggunakan Framework Codeigniter (Studi Kasus: Rumah Sakit Yukum Medical Centre). Jurnal Teknoinfo, 11(2), 30. https://doi.org/10.33365/jti.v11i2.24

[2] Hoesan, N., \& Manik, V. 2019. Aplikasi Pelayanan Jasa pada Laundry Berbasis Android Untuk Meningkatkan Pelayanan di Bisnis Laundry Pos. Jurnal Manajemen Bisnis, 22(1), 82-91.

[3] Rachmatika, R., \& Wulandari, R. D. 2019. Rancangan Aplikasi Laundry Berbasis Dekstop pada Krisna Laundry Untuk Wilayah Limo Design of Laundry Application Based on Decstop on Krisna Laundry for Limo Areas. Prosiding Seminar Nasional Informatika Dan Sistem Informasi, 4(1), 46-53.

[4] Mulyadi, B., Jaroji, \& T, A. 2019. Aplikasi Sistem Pemesanan Jasa Laundry (E-Laundry) Berbasis Android. ZONAsi: Jurnal Sistem Informasi, 1(1), 48-57. https://doi.org/10.31849/zn.v1i1.2386

[5] Atina, L., Hendrawan, N., \& Murati, M. O. 2020. Aplikasi Sistem Manajemen Laundry Berbasis Web Management System Application Laundry Web-Based. 9(2), 85-90.

[6] Khoirunnisa, R., Isnanto, R. R., \& Martono, K. T. 2016. Pembuatan Aplikasi Web Manajemen Laundry dan Integrasi Data Dengan Web Service. Jurnal Teknologi dan Sistem Komputer, 4(1), 93. https://doi.org/10.14710/jtsiskom.4.1.2016.93-101

[7] Prasanti, D. 2018. Penggunaan Media Komunikasi Bagi Remaja Perempuan Dalam Pencarian Informasi Kesehatan. LONTAR: Jurnal Ilmu Komunikasi, 6(1), 13-21. https://doi.org/10.30656/lontar.v6i1.645 
[8] Sugiyarta, A., Jubaedi, A. D., \& Pambudi, S. A. 2018. Sistem Informasi Skorsing Siswa Berbasis SMS Gateway di SMP Informatika Kota Serang. JSiI (Jurnal Sistem Informasi), 5(2), 34-39. https://doi.org/10.30656/jsii.v5i2.773

[9] Susanto, R., \& Andriana, A. D. 2016. Perbandingan Model Waterfall dan Prototyping Untuk Pengembangan Sistem Informasi. Therapie Der Gegenwart, 111(5), 756-757 passim.

[10] Tabrani, M. 2018. Penerapan Metode Waterfall pada Sistem Informasi Inventori PT. Pangan Sehat Sejahtera. Jurnal Inkofar, 1(2), 30-40. https://doi.org/10.46846/jurnalinkofar.v1i2.12

[11] Taluke, D., Lakat, R. S. M., Sembel, A., Mangrove, E., \& Bahwa, M. 2019. Analisis Preferensi Masyarakat Dalam Pengelolaan Ekosistem Mangrove di Pesisir Pantai Kecamatan Loloda Kabupaten Halmahera Barat. Spasial, 6(2), 531-540. 